\title{
PROUST JÓZEFA CZAPSKIEGO (NA TLE POLSKIEJ RECEPCJI)
}

\author{
Mieczysław DĄBROWSKI (Uniwersytet Warszawski)
}

Z popularyzacją dzieła Marcela Prousta związanych jest kilka ważnych dla polskiej kultury nazwisk; przypomnę je w tym eseju. Czapski jest tu, naturalnie, najważniejszy, jego bowiem wykłady o Prouście dla więźniów Griazowca stanowią fundament niniejszej publikacji ${ }^{1}$. Czapski zabrał głos na temat Prousta po lekturze francuskiego wydania W poszukiwaniu straconego czasu, gdy nie było jeszcze dostępne po polsku. W 1928 roku pisał między innymi:

Dopiero wczytując się w tekst uważnie, odczuwamy piękno, bogactwo i elastyczność tego indywidualnego stylu [...] Styl Prousta robi wrażenie wiecznego muskania, jego dotknięcie giętkie i chwiejne jak płomyk umie dotrzeć wszędzie, nie łamiąc ani nie deformując niczego, umie utrwalić najbardziej zwiewne, przelotne wrażenie ${ }^{2}$.

\section{Pierwsze reakcje na dzieło Prousta}

Walory tego stylu doceniali także inni czytelnicy francuskiego oryginału: Irena Krzywicka zwracała uwagę na ekonomię słowa („brak jakiegokolwiek zbędnego słowa") ${ }^{3}$, Anna Iwaszkiewiczowa trafnie odczytywała zarówno intencje autora, jak i pro-

\footnotetext{
${ }^{1}$ Niniejszy artykuł jest znacznie poszerzoną wersją tekstu pt. Proust $w$ Polsce: mała historia jego recepcji, opublikowanym po francusku Petite histoire de la réception de Proust en Pologne, thum. L. Waleryszak, [w:] À la recherche de "La Recherche". Les notes de Joseph Czapski sur Proust au camp de Griazowietz, 1940-1941 / Józef Czapskis Notate zu Proust im Gefangenenlager Grjazovec 1940/41, red. S. Mainberger, N. Stewart, Lausanne 2016, s. 89-104 i po niemiecku pt. Proust in Polen: eine kleine Geschichte seiner Rezeption, tamże, s. 105-121.

2 J. Czapski, Marceli Proust, Przegląd Współczesny 1928 nr 71, przedr. [w:] J. Czapski, Patrzac, wstęp, przedmowa i posłowie J. Pollakówna, wyd. II, Kraków 2004, s. 13-32, tu: s. 20. Wiele wypowiedzi przytaczam w tym artykule za książką Jerzego Domagalskiego Proust $w$ literaturze polskiej do 1945 roku (Warszawa 1995) lub za artykułem Jerzego Speiny Marcel Proust w Polsce. ,,W poszukiwaniu straconego czasu” - międzywojenna recepcja krytycznoliteracka, Pamiętnik Literacki 1992 R. 83 z. 2, s. 177-201.

${ }^{3}$ I. Krzywicka, Epos czasu, Wiadomości Literackie 1928 nr 20, s. 1.
} 
fetycznie zauważyła, w którą stronę pójdzie rozwój powieści dwudziestowiecznej. Pisała:

Te długie okresy, te nawiasy w nawiasach robią zresztą często wrażenie nie tyle konieczności artystycznej, nie właściwości immanentnej jego stylu, ile pewnej wewnętrznej potrzeby neurastenika: wszystko, wszystko opowiedzieć, wszystko wyrzucić z siebie, nawet jeśli to jest męką ${ }^{4}$.

W obszernym artykule opublikowanym rok później niezwykle precyzyjnie i czujnie rozpoznaje i opisuje styl Prousta, charakteryzuje sposób budowy zdania, sens świadomej kompozycji, muzyczność frazy, zmagania z problematyką czasu, drobiazgowością opisów, co bardzo dobrze świadczy o jej wrażliwości literackiej ${ }^{5}$. Wróciła do tych kwestii po przeczytaniu szesnastu tomów francuskiej edycji ${ }^{6}$, broniąc na przykład tezy, że już pierwszy tom, $W$ strone Swanna, zapowiada wszystkie motywy, rozwijane potem w kolejnych częściach ${ }^{7}$. To samo twierdził Czapski, jeden z wykładów w Griazowcu poświęcony był analizie pierwszego tomu $\mathrm{z}$ tego punktu widzenia („Przejrzyjmy te zasadnicze tematy: [...]"8) i wymieniał: prowincję francuską, tematy miłości i zazdrości związane z historią Swanna i Odetty, a dalej: arystokracja i burżuazja, studia nad ludzkimi zachowaniami i charakterami, muzyka i sztuka jako sublimacja uczuć itp. Czapski, Irena Krzywicka i Anna Iwaszkiewiczowa najtrafniej, z dzisiejszej perspektywy, rozpoznali zarówno charakter dzieła, jak i jego wartość (Anna Iwaszkiewiczowa wracała do niego kilka razy ${ }^{9}$ ). Po latach widać, że te rozpoznania i oceny nic nie straciły ze swej diagnostycznej wartości, a przeciwnie - wszystko, co później o sztuce pisarskiej Prousta powiedziano, zauważyli jako pierwsi. Czapski w wykładach z Griazowca wskazuje także na „chorobę nerwową”, która, zapoczątkowana w dzieciństwie, na zawsze już określiła charakter Prousta ${ }^{10}$, jego psychiczną i fizyczną kondycję.

Pierwsza w Polsce informacja na temat Prousta pochodzi z roku 1922 i wyszła spod pióra Marii Rakowskiej, która narzeka na styl „męczący i skomplikowany”, na „niebywałą długość” zdań oraz ich niejasną budowę, co skutkuje orzeczeniem, iż jest to „lektura ciężka i trudna”, chociaż autorka docenia wartość psychologicznych portretów postaci $^{11}$. Ale Leon Pomirowski oceniał, że właśnie te tomy tak ciężkie ,jak stacje kalwaryjskie”, gdy się je dobrze przeżyje, stają się „uszczęśliwiające, jak akty ofiarnej

${ }^{4}$ [A. Iwaszkiewiczowa] Adam Podkowiński (pseud.), [b.t.], Pamiętnik Warszawski $1931 \mathrm{nr} 6$.

${ }^{5}$ Taż, Sztuka Prousta, Wiadomości Literackie $1932 \mathrm{nr}$ 40, s. 3.

${ }^{6}$ P. Hertz, [wstęp do:] A. Iwaszkiewiczowa, Szkice $i$ wspomnienia, do druku podała M. Iwaszkiewicz-Wojdowska, Warszawa 1987, prostuje, że tych tomów było piętnaście (por. s. 53). Trzeba jednak dać wiarę Boyowi, który wielokrotnie mówi o wydaniu szesnastotomowym („Utwór $W$ poszukiwaniu straconego czasu [...] Obejmuje w oryginale szesnaście dużych tomów. Dzieli się na siedem części, każda po parę tomów"); T. Żeleński (Boy), Pisma, red. H. Markiewicz, t. 13: Obiad literacki. Proust i jego świat, Warszawa 1958, s. 162. Boy nosił się z zamiarem opublikowania tych tekstów w książce Proust $i$ jego świat, niestety wojna przekreśliła te plany. Pierwsze pełne wydanie PIW ukazało się właśnie jako siedmiotomowe, co odpowiada pierwotnemu podziałowi.

7 [Adam Podkowiński] A. Iwaszkiewiczowa (pseud.), Portret Prousta, cyt. za: J. Speina, Marcel Proust $w$ Polsce, s. 194.

${ }^{8}$ J. Czapski, Proust w Griazowcu, thum. z fr. T. Skórzewska, [w:] Czytając, Kraków 1990, s. 108-163, tu: 134.

${ }^{9}$ Także w szkicu Conrad a Proust z roku 1930, pierwodruk w: Twórczość 1984 nr 12, przedr. w: A. Iwaszkiewiczowa, Szkice i wspomnienia, s. 65-76.

${ }^{10}$ J. Czapski, Proust w Griazowcu, s. 137.

${ }^{11}$ M. Rakowska, Marcel Proust, Tydzień Polski 1922 nr 11. 
miłości” i prowadzą do „pokory, pojednania i zachwytu”12. Nie brakowało także głosów ostrzej wyrażających niechęć: Jana Dobraczyńskiego, Leona Piwińskiego i innych. Dobraczyński w 1939 roku pisał: „U Prousta nic się nie dzieje i ta ohydna jałowość straconego czasu dręczy i przeraża [...]. Powieść bez walorów literackich. [...] Fałsz psychologiczny zespala się z fałszem artystycznym. W książce nie ma nic prawdziwego" ${ }^{\text {- }}$ - trzeba przyznać, że to dość zdumiewająca opinia w ustach bądź co bądź pisarza i kompletnie obca wobec tego, co o Prouście już w Polsce napisano, zwłaszcza po publikacji kilkunastu tomów $W$ poszukiwaniu straconego czasu po polsku. Zofia Mianowska zarówno w treści, jak i sposobie opowiadania widzi „niedołęstwo”, według niej „zupełnie fałszywie brzmią nieskończone rozmowy”, a rysunek Albertyny i jej stała obecność w dziele (rozszyfrowanej zresztą trafnie jako powieściowy kamuflaż kochanka Prousta ${ }^{14}$ ), ocenione zostały jako twór nierealny, raczej ,pretekst autora do snucia rozważań na najróżniejsze tematy" ${ }^{\text {"15 }}$ zważywszy na miejsce publikacji jest to opinia dość kuriozalna. W całej tej recenzji znać irytację piszącej. Dziwić także może niejednoznaczna opinia Leona Piwińskiego, który wiele partii powieści określa jako martwe i nudne (np. życie towarzyskie, obiady itp.), ale dostrzega wartość w refleksji na temat sztuki i miłości, które znajdują „wyraz doskonały i rozstrzygający o jego żywotności trwającej do dziś" ${ }^{\prime \prime}$. Dostrzeżono także zmiany wobec tradycji dziewiętnastowiecznej w konstrukcji powieści, fabule i typie bohaterów, oceniane już to pozytywnie (Iwaszkiewiczowa: „Brak w utworze elementów sensacji, brak intryg”"17; Krzywicka: „Dzieło Prousta posiada wręcz naukową powagę, ścisłość, precyzję [...]"18), już to negatywnie (zob. wyżej).

To tylko wybrane przykłady wypowiedzi, których było relatywnie dużo. Bowiem polska kultura z przełomu dziewiętnastego i dwudziestego wieku z przedłużeniami w okres międzywojenny była wciąż przeniknięta duchem francuszczyzny. Jan Lechoń napisał po śmieci pisarza wiersz, zatytułowany Proust, wart przytoczenia:

\footnotetext{
W półmroku sennej lampy jakieś dziwne cienie, Zapach lekarstw duszący, twarz blada jak chusta. To nic. To tylko zwykłe ostatnie zdarzenie, I trudno, by dziwiło Marcelego Prousta.

Jak słońce, gasnąc w pysznych promieni efekcie, Zachodzić się nie wzbrania i świecić nie żąda, Tak on powoli opis poprawia w korekcie Tej śmierci, którą widzi i wie, jak wygląda. $[\ldots]^{19}$.
}

${ }^{12}$ L. Pomirowski, Dzieło Marcelego Prousta. Artysta i człowiek, Wiadomości Literackie $1925 \mathrm{nr} 15$, s. 2.

${ }^{13}$ J. Dobraczyński, Proust na ruinach miast Pentapolu, Prosto z Mostu 1939 nr 23, s. 7.

${ }^{14}$ Boy pisał ostrożniej, ale czujnie: „W niektórych częściach utworu czuć jakby transpozycje płci, nawet kosztem prawdopodobieństwa sytuacji”; Obiad literacki, s. 167. Mówi także o ,zuchwalstwie obyczajowym” w związku z baronem Charlusem; tamże.

${ }^{15}$ Z. Mianowska, Rocznik Literacki 1939 (dział „Przekłady”).

${ }^{16}$ L. Piwiński, Marcel Proust. „W poszukiwaniu straconego czasu”: „W stronę Swanna”. „,W cieniu zakwitających dziewcząt”, Życie Literackie 1937 z. 4, s. 146-147.

${ }^{17}$ [Anna Iwaszkiewiczowa] Adam Podkowiński (pseud.), Sztuka Prousta, s. 3.

${ }^{18}$ I. Krzywicka, Epos czasu, s. 1.

${ }^{19}$ Jan Lechoń, Srebrne i czarne, Warszawa 1924, s. 9. 
Pierwsze komunikaty dotyczące Prousta i jego dzieła były formułowane na podstawie wydania francuskiego. Dopiero krytyka późnych lat trzydziestych mogła się odnieść do wydania Prousta po polsku, które przygotował Tadeusz Żeleński-Boy ${ }^{20}$. Wtedy doszedł do głosu także wątek antysemicki: ponieważ matka Prousta była Żydówką, polscy antysemici uczynili z tego faktu dodatkowy zarzut. Adolf Nowaczyński napisał, że Proust „,był dziedzicznie obciążonym owocem skrzyżowania dwóch ras”, przy czym zaznacza, że rodzina ojca się nie liczyła; ton jej życiu nadawać miała bogata semicka matka ${ }^{21}$. Gałczyński, którego antysemickie wypowiedzi traktowano czasami jako niewinne wybryki, napisał jednak słowa niemożliwe do zaakceptowania:

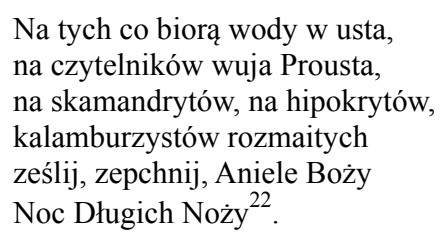

Ogólny odbiór pojawiających się między 1937 a 1939 rokiem tomów dzieła był dobry, choć też — na ogół — powierzchowny, impresyjny; poważnego studium ani na temat dzieła samego, ani jego przekładu nie napisano. W tych wzmiankach, felietonach, recenzjach i artykułach zarzucano Boyowi uproszczenia i ułatwienia. Henryk Elzenberg pisał o przekładzie Boya, że miejscami bywa „trochę niedbały”, że „,co krok pojawiają się skróty rzeczowo przeważnie dość nieszkodliwe, ale [...] trochę fałszujące styl Prousta"23, zaś Konstanty Troczyński nazwał Boyowskie operacje na tekście Prousta „przeróbkami dla dzieci”24, mając na myśli rozbijanie długich okresów zdaniowych, częstsze stosowanie akapitów, uformowanie dialogów w postać „rozmówek” wszystko razem oznacza (według poznańskiego teoretyka literatury) brak wierności filologicznej, co w rezultacie z eposu uczyniło literaturę dla dzieci.

\section{Boy o Prouście i swoim przekładzie}

Tadeusz Żeleński-Boy to najbardziej zasłużony tłumacz literatury francuskiej na język polski; za przekład dzieł Moliera otrzymał w 1914 palmy Akademii Francuskiej, w 1927 Krzyż Oficerski Legii Honorowej, a w 1934 Krzyż Komandorski Legii Honorowej. Znana jest fotografia, na której stoi obok przełożonych przez siebie dzieł literatury francuskiej: sterta tomów ułożonych jeden na drugim jest wyższa niż on sam. Pierwszy artykuł na temat Prousta, Nowe słońce literatury opublikował w roku $1924^{25}$, już wtedy podkreślając autobiograficzny charakter dzieła, gdzie przeżyte doświadczenie ulega artystycznemu przetworzeniu. W latach 1938-1939 wystąpił z serią artykułów na łamach „Wiadomości Literackich” przy okazji pojawiania się w księgarniach

${ }^{20}$ Nakładem Towarzystwa Wydawniczego „Rój” ukazały się w latach 1937-1939 następujące części cyklu M. Prousta w przekładzie Boya: 1. W stronę Swanna (t. 1-3, 1937), 2. W cieniu zakwitajacych dziewcząt (t. 1-3, 1937), 3. Strona Guermantes (cz. 1, t. 1-2, 1938), 4. Strona Guermantes (cz. 2, t. 1-2, 1938), 5. Sodoma i Gomora (t. 1-3, 1939), 6. Uwięziona (t. 1-2, 1939).

${ }^{21}$ A. Nowaczyński, Do Prusa, nie do Prousta, Myśl Narodowa 1929 nr 6, s. 83-85.

${ }^{22}$ K. I. Gałczyński, Antyfona, Prosto z Mostu 1937 nr 9, s. 1.

${ }^{23}$ H. Elzenberg, Literatura francuska, Rocznik Literacki 1936, s. 131-132.

${ }^{24}$ K. Troczyński, Prousta wydanie dla dzieci. Impresje laika, Dziennik Poznański 1937 nr 256.

${ }^{25}$ T. Boy-Żeleński, Nowe słońce literatury, Kurier Poranny $1924 \mathrm{nr} 45$, przedr. w: Obiad literacki, s. 353-359. 
kolejnych tomów Poszukiwania straconego czasu w swoim przekładzie. Zebrało się tych wypowiedzi kilkanaście, po wojnie zostały opublikowane w tomie Obiad literacki. Proust i jego świat ${ }^{26}$. Jest to wciąż w Polsce największy zespół tekstów krytycznych o Prouście, napisanych przez jednego autora. „Przygrywką” do nich był artykuł Nowe oblicze Prousta, opublikowany w „Wiadomościach Literackich” w 1935 roku, gdzie zajmuje się m.in. tzw. stylometrią, czyli badaniami nad stylem pisarza z pierwszego tomu i dalszych, już przepracowanych w czasie Wielkiej Wojny (mówi - za profesorem Feuilleratem - o ,pierwszym i drugim Prouście”; z wielu uwag technicznych i szczegółowych można się domyślać, że jest to artykuł z okresu intensywnej pracy thumaczeniowej $)^{27}$.

Boy thumaczy w nich pisarza i jego twórczość, udowadnia, jak wielkie znaczenie dla tego opus magnum miała biografia Prousta, środowisko, w którym się wychował, dorastał i dojrzewał pisarsko, zamożność, rzutująca na charakter zainteresowań pisarskich, oraz homoseksualizm, gdyż ten rodzaj miłości praktykował i stał się niemal jego monografistą ${ }^{28}$, sposób pojmowania sztuki i techniki pisarskie ${ }^{29}$. Stale podkreślał zasadę przetwarzania rzeczywistości w dzieło sztuki. Uwzględnił także francuską tradycję piśmienniczą, która Prousta ukształtowała (wskazywał przede wszystkim na Montaigne'a, Saint-Simona, Stendhala, Balzaka ${ }^{30}$ ), tło polityczne dziewiętnastowiecznej Francji, stratyfikację społeczną, arystokratyczne szczyty i środowiskowe snobizmy. Według Boya $W$ poszukiwaniu straconego czasu jest dziełem silnie osadzonym w tym środowisku, racjonalizuje i dyskursywizuje wszystko, co dotyczy francuskiego mieszczaństwa i arystokracji, przede wszystkim zaś to, co wpływa na kształt ówczesnej sztuki (malarstwo, literatura, muzyka), jak i na charaktery ludzkie (w tym rolę znanych salonów literackich prowadzonych przez wpływowe kobiety). Porównuje Prousta do Balzaka w zamiarze ukazania „komedii ludzkiej”, gdzie jednak nie ma nędzy i kultu pieniądza (przynajmniej się o nich nie mówi), gdyż tych aspektów życia społecznego Proust nie znał i nie wprowadzał do tekstu.

Pojawiają się też w tych esejach uwagi dotyczące samego thumaczenia. Boy nie ukrywa, że rozbijał niemożliwie długie okresy zdaniowe Prousta, stosował częściej akapity niż ma to miejsce $\mathrm{w}$ oryginale. Tłumaczył to tym, że język polski, zwłaszcza jego struktura składniowa, mniej złożona i rozbudowana niż francuska, nie jest w stanie wytrzymać tylu wtrąceń, zdań podrzędnych, uzupełnień i dopowiedzeń (słynne „nawiasy w nawiasach” przywołane przez Czapskiego w Griazowcu), ile się ich znajduje we francuskim tekście, że więc zmuszony był — dla czytelności — dzielić te zbyt dhugie fragmenty na mniejsze odcinki ${ }^{31}$. Znany był w związku $\mathrm{z}$ tym $\mathrm{w}$ przedwojennej

\footnotetext{
${ }^{26}$ Por. informacje z przyp. 6 .

${ }^{27}$ T. Żeleński-Boy, Nowe oblicze Prousta, Wiadomości Literackie 1935 nr 44, s. 2, przedr. w: Obiad literacki, s. 360-374, tu s. 365 (w oryginale druk rozstrzelony).

28, ,...] całe dzieło Prousta mogłoby się wydawać niemal monografią homoseksualizmu [...]"; tamże, s. 372-373.

${ }_{29}$ Podkreślał to także J. Speina w swoim studium, nazywając to podejściem socjologicznym, interpretacja taka ,nie rezygnując z rozpoznania budowy dzieła, może sobie pozwolić na uwzględnienie nieodłącznej a utajonej w nim obecności autora, na wyjście poza dzieło i odwoływanie się do jego źródeł społecznych, obyczajowych i psychologicznych [...]”; J. Speina, Marcel Proust w Polsce, s. 180

${ }^{30}$ „Ten pisarz, streszczający w sobie całą niemal literacką Francję, najbliższy jest pod wieloma względami owego wieku XVII [...]”; T. Żeleński-Boy, Obiad literacki, s. 294.

31 „Zarazem pozwoliłem sobie poczynić pewne zmiany w układzie drukarskim, zwiększając liczbę akapitów oraz wyodrębniając dialogi, co niewątpliwie przyczynia się do czytelności książki. Nie sądzę, bym był przez to w niezgodzie z intencjami Prousta [...]”, tamże, s. 172.
} 
Warszawie dowcip - Czapski go przywołuje ${ }^{32}$ — że dopiero tak uformowane dzieło Prousta powinno być przełożone na francuski, co by mu zapewniło rzeczywistą poczytnośćc $^{33}$. To efektowny żarcik, który z rzeczywistością nie miał wiele wspólnego: Francuzi bardzo szybko docenili wartość dzieła swojego rodaka, można powiedzieć, że po Nagrodzie Goncourtów z 1919 roku Proust stał się niekwestionowanym klasykiem za życia, kończył je w powszechnej sławie.

To pokazuje od razu praktyczne problemy tłumacza, który w tym sensie jest najlepszym przykładem komparatysty. Jak wiadomo, Boy nie tylko rozbijał zbyt długie okresy zdaniowe Prousta, ale niekiedy pomijał te fragmenty, które wydawały mu się z punktu widzenia czytelnika polskiego nieistotne (to stary i dobrze znany trik dawniejszych thumaczy, dzisiaj raczej niepraktykowany ze względu na bardziej restrykcyjne przepisy prawa autorskiego). Trzeba jednak powiedzieć, że wersja Boya jest wciąż obowiązująca, nie pojawił się, jak dotąd, konkurencyjny przekład całości, którego dokonał Boy w latach 30. XX wieku. Ukazało się wtedy pięć części (w 16 woluminach), przekłady dwóch ostatnich zaginęły we Lwowie w czasie wojny, dokąd Boy uciekł z Warszawy i gdzie w nocy z 3 na 4 lipca 1941 został aresztowany przez specjalną grupę gestapo pod dowództwem dra Karla Eberharda Schöngartha i tej samej nocy zamordowany wraz z grupą polskich profesorów lwowskich uczelni. Dlatego pełne wydanie $W$ poszukiwaniu straconego czasu, które przygotował Państwowy Instytut Wydawniczy w latach 1957-1960, składa się z pięciu tomów w przekładzie Boya, tomu szóstego w przekładzie Macieja Żurowskiego, profesora romanistyki Uniwersytetu Warszawskiego i tomu siódmego, zatytułowanego Czas odnaleziony, który przełożył Julian Rogoziński (tę część ponownie przełożył M. Żurowski, Warszawa 2001). Tom szósty, Utracona (obocznie tytułowany Nie ma Albertyny), ukazał się także w nowym przekładzie pisarki, Magdaleny Tulli, w 2001 roku. Drugi wątek, poruszany przez Boya jako tłumacza, to pierwodruk dzieła Prousta, do którego aluzje znajdują się także w wykładach Czapskiego ${ }^{34}$. Otóż było to wydanie kiepskiej jakości, oszczędnie gospodarujące światłem, drukowane gęsto na marnym papierze, słowem: typografia, która uwzględniała zastrzeżenia wydawców co do długości tekstu, pozwalała zmniejszyć koszty (wiadomo, że publikację pierwszego tomu Proust sfinansował, wydawca Grasset dał mu tylko szyld), ale sprowadzała dzieło do poziomu wydania niemal broszurowego i trudno czytelnego.

\section{Proust w oczach Jana Błońskiego}

Eseje Boya nie wnikały szczególnie głęboko w artystyczną strukturę samego dzieła; ich autora zajmowały okoliczności jego powstania: stosunki środowiskowe, homoerotyzm $^{35}$ i astma Prousta, polityka, socjologia opisywanych środowisk, wreszcie kwe-

${ }^{32}$ Por.: J. Czapski, Proust w Griazowcu, s. 130.

33 Por. zapis Boya: „Albo znów chwalono mnie — równie dowolnie — za piękną «transkrypcję» Prousta, którego jakoby napisałem na nowo po polsku itp."; T. Żeleński-Boy, Obiad literacki, s. 343.

${ }^{34}$ Boy mówi, że $W$ stronę Swanna ,wypadło najnieczytelniejsze wydanie pod słońcem" i dlatego ,starając się uzyskać przejrzystość i czytelność książki, przywracając dialogom ich graficzny sens, tłumacz polski był w tym wierny prawdziwym intencjom Prousta"; tamże, s. 204. Tę nieczytelność potwierdza także Stanisława Przybyszewska; zob.: J. Domagalski, Proust w literaturze polskiej, s. 66 i n.

${ }^{35}$ Boy sugeruje, że intymna znajomość z Agostinellim, a niedługo jego śmierć (przetransponowane w dziele na postać Albertyny), wywołały radykalną zmianę proporcji w kompozycji całego dzieła, rozdymając właśnie ten wątek; por.: T. Żeleński-Boy, Obiad literacki, s. 289. 
stie techniczne ${ }^{36}$. Brak ten chciał wypełnić Jan Błoński w niewielkiej książeczce, zatytułowanej Widzieć jasno w zachwyceniu. Szkic literacki o twórczości Prousta ${ }^{37}$. Podkreślam słowo „literacki” zawarte w podtytule, gdyż to go odróżnia od socjologiczno-historyczno-obyczajowych esejów Boya, o których Błoński wyraża się z lekkim przekąsem. Co zajmuje jego samego? Kilka spraw należących do estetyki i filozofii literatury. Po pierwsze, konstrukcja tekstu (model „katedry”, narrator personalny: „pan, który mówi”), gdzie pojawiają się uwagi takie jak u Boya, tzn. dotyczące pierwotnej, przedwojennej i wtórnej — z okresu I wojny — budowy tekstu, kiedy to Proust odsuwa się coraz bardziej od życia towarzyskiego, zaszywa w domowym azylu i przepracowuje tekst, napisany w latach 1909-1912. Niezmieniony został tylko tom pierwszy, $W$ strone Swanna, który ukazał się już w roku 1913, dalsze uległy daleko idącym przeróbkom stylistycznym ${ }^{38}$. Błoński wyraża to efektownym kalamburem, że w pierwszym tomie wspomnienie rządziło pisarzem, w partiach przerobionych zaś to pisarz rządzi wspomnieniami ${ }^{39}$, podkreślając tym przejście od stylu impresjonistycznego do intelektualnego, który oznaczał niemal naukowo rozumianą analizę psychologiczną.

Boy powołuje się na Alberta Feuillerata, który poddał precyzyjnej analizie stylistycznej te teksty i był w stanie dość wyraźnie określić, które partie pochodzą sprzed wojny, które zaś zostały dodane w sytuacji przymusowej zwłoki w publikacjach ${ }^{40}$. Jako thumacza, analizy te Boya fascynowały. Błońskiego interesuje psychologia postaci, ich cierpienia i radości, sposób ich przeżywania i mowy. Prousta powszechnie czytano, mając w pamięci koncepcje Freuda, ale zdarzały się głosy, które mówiły, że ten wyprzedził wnioski wiedeńskiego psychoanalityka. Krakowski krytyk analizuje zwłaszcza fenomen miłości, w tym miłości homoseksualnej, a także, niezmiernie tu ważny, fenomen czasu oraz środowiskowych snobizmów.

Snobizm - pisze - jest obyczajowym wyrazem nieautentyczności: ulegamy mu wte-

dy, gdy przypisujemy znaczenie ludziom i wartościom, ale nie tym, które swobodnie wybraliśmy, lecz takim, którym hołduje otoczenie ${ }^{41}$.

I problematyka czasu, i snobizmu znalazły się w centrum uwagi polskich krytyków Prousta, głosy te skrupulatnie przypomina Jerzy Speina w swoim kompetentnym studium. Ale na ogół pisano o tym w taki sposób, jakoby sam Proust miał być snobem. Może i był, w młodości, gdy starał się dostać do towarzystwa arystokracji i plutokracji. Czapski zwraca jednak uwagę, że gdy już to środowisko dobrze poznał, to właśnie jego

${ }^{36}$ „Proust mógłby być interesującym argumentem w dyskusji nad tezą «formalistów» żądających odłączenia dzieła od człowieka, twierdzących, iż wiedza nasza o pisarzu-człowieku raczej przeszkadza, niż pomaga do zrozumienia utworu. Otóż sam Proust by wystarczył, aby postawić pod znakiem zapytania uniwersalność tej surowej tezy [...]”, tamże, s. 280.

37 J. Błoński, Widzieć jasno w zachwyceniu. Szkic literacki o twórczości Prousta, Kraków 1985.

38 „Dzieło Prousta gotowe było od dawna, bez tych przeszkód ukazałoby się przed wojną w całości, w swojej pierwotnej postaci. [...] wojna przerwała korekty z drugiej części, czego następstwem było - jak wiadomo - wzięcie całego dzieła jeszcze raz na warsztat w czasie przymusowej czteroletniej pauzy i napisanie go niemal na nowo", T. Żeleński-Boy, Obiad literacki, s. 341.

${ }^{39}$ J. Błoński, Widzieć jasno w zachwyceniu, s. 96.

${ }^{40}$ Por.: A. Feuillerat, Comment Marcel Proust a composé son roman, New Haven 1934.

${ }^{41}$ J. Błoński, Widzieć jasno w zachwyceniu, s. 66. Problematykę snobizmu rozpatrywała często krytyka międzywojenna, ponieważ był to czas paradygmatycznej zmiany $\mathrm{w}$ tej materii, jaką wywołała Wielka Wojna; o nowych regułach środowiskowej gry mówi także Proust w ostatnim tomie, w rozdziale Koncert u Guermantesów. 
głupotę, płaskość i snobizm krytykował najbardziej (najlepszym przykładem jest pani Verdeurin, bogata mieszczka $\mathrm{z}$ ambicjami, i jej salon) ${ }^{42}$.

Błoński, zawsze w swoich analizach subtelny, znalazł i tym razem szczególny sposób mówienia na ten temat. Bardzo zajmujący - wtedy, w początkach lat osiemdziesiątych, ale czy także dzisiaj? Postępująca antropologizacja i kulturologizacja badań literaturoznawczych sprawiły, że te dociekania — świetne 1 i t e r a c k o, zanurzone jeszcze w strukturalistycznym typie analizy — nie do końca trafiają we współczesną wrażliwość. Bardziej aktualny wydaje się znowu Żeleński-Boy ze swoimi uwagami na temat głębokiego wiązania, jakie łączy życie Prousta z jego dziełem i sytuacją historyczną, cała sfera, powiedzmy, swobodnie rozumianej geopoetyki tego wielkiego dzieła. Geopoetyki i imagologii, a także artystycznie przetworzonej biografii ${ }^{i 3}$, czyli tych aspektów, które animują współczesną refleksję o tekście literackim. Także proustowskie rozumienie kultury w sensie zarówno efektów modelowania zachowań przez określone układy społeczne, jak też jego oddziaływania na czytelników i rozwój prozy w dwudziestym wieku, a także liczne zapożyczenia i cytaty, mniej czy bardziej czytelne, co dziś nazywa się ogólnie terminem intertekstualność. Chodzi o to, że Proust odszedł od modelu powieści dziewiętnastowiecznej, gdzie dominowała fabuła i przezroczysty język, zaś w sferze społecznej pominął rewolucyjne dążenia, połączone z kapitałem, i wytworzył powieść $\mathrm{w}$ formie wspomnieniowo-eseistyczną ${ }^{44}$, a w zamiarze filozoficzną, gdzie najważniejsze są kwestie psychologii postaci, pamięci, estetycznego przeżywania, czasu, metafizyki sztuki, badania natury ludzkiej, sieci zależności emocjonalnych, którymi zastąpił dawniejsze powiązania konstytuowane przez urodzenie lub/i pieniądz, a konstrukcyjnie przez chronologię i regułę przyczynowo-skutkową.

\section{Czapski versus Proust}

Czapski w wykładach z Griazowca, ale również później, w swoich licznych i słynnych „,kajetach” z codziennymi zapiskami (częściowo opublikowanymi) wielokrotnie wraca do Prousta, jest on jednym z wiecznych i dyżurnych źródeł cytatów, jego — jak to nazywał — „złotych gwoździ”. „[C]zytał Prousta stale” — potwierdza Karpiński ${ }^{45}$.

${ }^{42}$ „Proust dobrze widzi niesłychane ubóstwo moralne i umysłowe lwiej części tego thumu próżnych światowców i pysznych arystokratów, goniących za zabawą i rozpustą"; J. Czapski, Marceli Proust, [w:] tegoż, Patrząc, s. 27.

${ }^{43}$ Por.: S. Nalbantian, Aesthetic Autobiography: From Live to Art in Marcel Proust, James Joyce, Virginia Woolf, and Anais Nin, New York 1994. Boy w swoich szkicach o dziele Prousta wielokrotnie podkreśla jego autobiograficzny charakter: „,dzieło jego ma charakter autobiograficzny”; T. Żeleński-Boy, Obiad literacki, s. 177, także 163, 233. „Powieściową autobiografią” nazywa dzieło Prousta Karol Irzykowski; por.: K. Irzykowski, Autobiografizm, Rocznik Literacki 1936, s. 6. Autobiograficzny charakter dzieła postrzega także Czapski: „Każde wielkie dzieło jest głęboko i na różne sposoby związane z samą materią życia autora. To związanie jest jednak szczególnie widoczne, bardziej może zupełne w dziele Prousta. Bo samym tematem $W$ poszukiwaniu straconego czasu jest przetransponowane życie autora. Główny bohater opowiada je w pierwszej osobie, a wiele stronic robi wrażenie ledwie zamaskowanej spowiedzi"; J. Czapski, Proust w Griazowcu, s. 116.

${ }^{44} \mathrm{Na}$ ten wątek zwracał trafnie uwagę Tadeusz Breza; Dwugłos o B. Micińskim, Ateneum 1938 nr 2. Tę cechę Poszukiwania podkreślał także Boy; Obiad literacki, s. 202.

${ }^{45}$ W. Karpiński, Portret Czapskiego, Warszawa 2007, s. 12. Czapski potwierdza to w Griazowcu: „Później nieskończoną ilość razy powracałem do tych książek, i dostrzegałem w nich coraz to nowe akcenty, nowe perspektywy”; „Za każdym nawrotem do Prousta, a powracałem do niego wiele razy, odkrywałem nowe akcenty, nowe piękności, nie zauważone przeze mnie najwnikliwsze uwagi i myśli”; por.: J. Czapski, Proust w Griazowcu, s. 112 i 141. 
Ta lektura stała się istotnym elementem jego duchowej biografii, a zatem tego, co jedynie cenił: doświadczenia indywidualnego. Doświadczenia materialnego, fizycznego, jak i doświadczenia symbolicznego, duchowego. „Co nie jest biografią — nie jest w ogóle" - wynotował aprobująco z Brzozowskiego ${ }^{46}$, rozszerzając pojęcie biografii także na doświadczenia intelektualno-estetyczne. W jego przypadku biografia to nie tylko wielkoświatowe koneksje czy wojenne przygody - to także codzienne lektury i zapiski dziennikowe czynione albo z rana (Przed praca), zanim jeszcze zabrał się do malarskiego „piłowania martwej”,47, albo po pracy (częste w jego dziennikach zapiski oznaczane zwrotem Po pracy). Z tego widać, że malarstwo to była jego właściwa „praca”, pisanie zaś - poboczne zajęcie, które stało się nawykiem, potrzebą, a w końcu i chwałą, może i największą. Dzienniki pokazują, jak bardzo styl Czapskiego przypomina styl Prousta: powojenny lokator małej dziupli w domu „Kultury” w Maisons-Laffitte nieustannie drąży kwestie własnej i cudzej duchowości, lecz przede wszystkim zadaje pytania estetyczne, moralne oraz techniczne, dotyczące pisania i malowania. Jak wiadomo, był jednym i drugim, już Wspomnienia starobielskie i Na nieludzkiej ziemi dały mu trwałe miejsce w literaturze, krytyka sądzi, że ze swoim szczególnym diariuszem postawił mocno stopę w dwudziestowiecznej intymistyce. Pisał coraz lepiej, zdania z jego późniejszych dzienników toczą się gładko, potoczyście, nie gubiąc jednak podstawowego nurtu. W porównaniu z jego pierwszą wypowiedzią o Prouście z 1928 roku jest to zupełnie inna klasa pisarstwa. Sam wielokrotnie rozważał kwestię, kim jest bardziej: pisarzem czy malarzem. Chce być głównie malarzem, to jest jego podstawowa ambicja i refleksja nad malarstwem, cudzym i swoim, klasycznym i współczesnym, nad technikami i osobistymi ograniczeniami w tej dziedzinie zajmuje w kajetach (drukowanych i nie) wiele miejsca. I niepostrzeżenie te „kajety” czynią z niego pisarza, który subtelnym, dociekliwym i szczerym językiem zapisuje swoje egzystencjalne doświadczenie $^{48}$, bo malarstwo jest zarazem filozofią istnienia i refleksją fachowca. „Sztuka dla niego jest funkcją obiektywnej metafizyki o chrześcijańskim podłożu" — komentuje zwięźle zjawisko przyjaciel, Konstanty Jeleński ${ }^{49}$.

Dla Czapskiego rozmowa ważna to ta o życiu czy o sztuce, nigdy o dobrach materialnych, taka, która prowadzi do metafizyki. Można oczywiście zastanawiać się, dlaczego ten światły człowiek akurat z pism Simone Weil uczynił sobie punkt odniesienia dla rozważań moralnych, które w związku z tym krążyły wokół wiary, Kościoła katolickiego, Boga, czystości, życia pośmiertnego, mistycyzmu etc. (Brzozowski określa to jako ,zabobon o Bogu" ${ }^{, 50}$ ). Wiele jego udręk brało się właśnie z tych lektur, które stawiały mu zbyt wysokie poprzeczki, stanowiły wyzwanie moralne i intelektualne. „Simone Weil? Nie umiem znaleźć miary porównania z nią, dla mnie to wzór najwyższy w swoim okrutnym wyzwoleniu z małości życia" — pisał ${ }^{51}$. Czapski czuł, że musi dać temu wyraz w dziennikach, kłócił się z Weil, czuł się wprawdzie bardziej umocowany w miłości do ziemi i ludzi niż w ascezie i abstrakcyjnym Bogu ${ }^{52}$, ale jej świat uważał

\footnotetext{
${ }^{46}$ W. Karpiński, Portret Czapskiego, s. 135.

${ }^{47}$ Zob.: J. Czapski, Wyrwane strony, Warszawa 2010, s. 106.

${ }^{48}$ Tenże, Świat w moich oczach. Rozmowy przeprowadził Piotr Kłoczowski, Paryż-Ząbki 2001.

${ }^{49}$ K. A. Jeleński, Czyste malarstwo czy poetyka, [w:] Czapski i krytycy. Antologia tekstów, wybór i oprac. M. Kitowska-Łysiak, M. Ujma, Lublin 1996, s. 295, podkr. oryginalne.

${ }^{50}$ J. Czapski, O Stanisławie Brzozowskim, [w:] tegoż, Patrzą, s. 288.

${ }^{51}$ Tenże, Rozrachunki, [w:] tegoż, Czytajac, s. 468.

$52,[. .$.$] pociągała mnie [...] ta bliskość fizjologii i metafizyki”; J. Czapski, Ja, [w:] tegoż,$ Czytajac, s. 166.
} 
za niedościgły a pożądany idea1 ${ }^{53}$. Weil, a z drugiej strony Rosjanin, Wasilij Wasiljewicz Rozanow, który jest pars pro toto duszy rosyjskiej — od zwykłego raba po najwybitniejszych pisarzy, Lwa Tołstoja czy Fiodora Dostojewskiego — zanurzonej w refleksji o Bogu. Bez tego pewnie byśmy nie wiedzieli, jak bardzo można się poczuć określonym, zawładniętym przez jeden wątek i jak wiele można na ten temat powiedzieć. Inna rzecz, czy to jest równie zajmujące dla każdego czytelnika, zwłaszcza dzisiaj. Te jego duchowe dramaty, rozdarcia na tle religijnym dla wielu nowoczesnych czytelników mogą się wydać abstrakcją, dla niego nie były. Przy okazji wspominania śmierci matki powie, że „ta cała wielkość i groza samego istnienia w kategoriach zła i dobra, winy i kary, stwarzała wielkość i grozę śmierci" ${ }^{54}$. A o śmierci Czapski rozprawia stale, już w latach 60. XX wieku pisał o sobie, że jest „,stary” (a żył potem jeszcze około trzydziestu lat, urodzony w 1896, zmarł w 1993 roku).

Te wszystkie pytania stanowią o różnicy między słowiańskim a zachodnim sposobem myślenia: u wielkich pisarzy Zachodu - Tomasza Manna, Marcela Prousta, Jamesa Joyce'a, Roberta Musila i in. - nie mówi się o Bogu, a jeśli o Kościele, to jako o instytucji, która ma swoją nie najlepszą historię. Żaden z nich nie wikła jednak pojedynczego losu w wielkie dylematy religijne, na które nie było i nie ma jasnej odpowiedzi. Ich metafizyka była metafizyką poznania, metafizyką sztuki, metafizyką cierpienia lub rozkoszy, metafizyką doświadczenia duchowego (przeżycia), ale nie metafizyką krzyża i cierpienia, jak na Wschodzie. Im bardziej na Wschód, tym bardziej problematyka religijna zyskuje na znaczeniu w dyskursie publicznym i także w literaturze.

Dla Czapskiego refleksja moralna w kontekście wiary (przywoływał tu często Stanisława Brzozowskiego i Cypriana Norwida) to jest wieczny temat, oprócz, rzecz jasna, malarstwa i pisarstwa. Lęka się pośmiertnej nicości, ale zarazem wyznaje, że trudno mu „uwierzyć w nieśmiertelność" ${ }^{55}$. Na szczęście, mimo własnego światopoglądu, który był mocno naznaczony doktryną katolicką, potrafił lojalnie odczytywać Prousta i stanowczo stwierdzał, że w całym dziele wielki pisarz „nie wymawia słowa „Bóg” czy „religia”, ${ }^{56}$ lecz jego zaprzedanie dziełu i sztuce pisarskiej jako takiej określa mianem religijności ${ }^{57}$. Podkreślał, że aby dobrze zrozumieć Prousta, trzeba poznać jego dzieło jako skonstruowaną całość ${ }^{58}$, ukształtowaną w analitycznym języku (tamże) zgodnie z przeświadczeniem narratora, wyrażonym w ostatnim tomie, że pisarz jest przede wszystkim tłumaczem wrażeń, tłumaczem świata, a jego dzieło winno dać czytelnikowi narzędzia do ukształtowania własnego „warsztatu poznania”.

Język Czapskiego jest w znacznym stopniu językiem Prousta, ale nie w sensie samej konstrukcji wypowiedzi (bo jest raczej zwięzły i zdyscyplinowany, skrótowy), tylko w sensie zaprzedania się jednemu tematowi, nieustającej analizie, pogłębianiu tematu i dorzucaniu do niego wciąż nowych zauważeń i wniosków. Wniosków, które w następnym fragmencie mogą ulec - i ulegają! - radykalnym przemianom, jak u pierwowzoru. Nie ma w nich jednak wątków erotycznych, już w Griazowcu wątek ho-

\footnotetext{
${ }^{53}$ Tenże, Świat w moich oczach, s. 132 i n.

${ }^{54}$ Tenże, Wyrwane strony, s. 200.

${ }^{55}$ Tamże, s. 47-48, por. także s. 215.

${ }^{56}$ J. Czapski, Marceli Proust, s. 31.

${ }^{57}$ Tamże, s. 30: „Czyż można inaczej nazwać stosunek Prousta do sztuki, jeżeli nie re li g i j n y m", podkr. oryginalne.

58, ,[...] wcale nie jest pewne, czy Proust w transpozycji nie ściągnął tysiąca drobnych odruchów, olśnień świadomości w jedno czy parę przeżyć dominujących”; por. J. Czapski, Wyrwane strony, s. 107.
} 
moseksualizmu Prousta poruszył bardzo delikatnie ${ }^{59}$, o swoich doświadczeniach $\mathrm{z}$ tego zakresu pisze $\mathrm{w}$ dziennikach rzadko i ostrożnie ${ }^{60}$. Wszelkie kontakty o charakterze erotycznym uważał po latach za pozbawione sensu, jałowe i potęgujące samotnośćc ${ }^{61}$. W całym jego pisarstwie, intymnym i ,publicznym”, pojawia się kategoria pamięci, pamięci zarówno mimowolnej, jak i świadomej, pożądanej. Długie i bogate w rozmaite skrajności losu życie złożyło w jego głowie niezmierzone ilości obrazów, klisz, wątków. Wydobywa je niekiedy świadomie, gdy na przykład opowiada w filmie biograficznym o swoim życiu, ale najczęściej podświadomie, gdy pojawiają się obrazy znikąd — wtedy, gdy pisze w swoich „kajetach”. Maria Janion słusznie zauważa tu pewną paralelę z jego „ukochanym pisarzem", polegającą na tym, że niekiedy jakaś jedna scena, jeden obraz potrafi skupić w sobie wiele drobnych, rozciągniętych w czasie zauważeń ${ }^{62}$. Swoją pracę malarską, cierpliwość w ponawianiu malarskich czynności połączonych z jednoczesną refleksją teoretyczną tak nad swoim malowaniem, jak i nad malarstwem jako sztuką, sytuuje chętnie wobec tych wielkich postaci, w tym Prousta, w których urzekała go swoista metafizyka moralnej doskonałości siebie lub technicznej doskonałości dzieła, przekraczanie własnych ograniczeń i słabości w imię jakiegoś ideału. Czapski był kontynuatorem, być może już jednym z ostatnich, tej postawy artystycznej, która nie myślała jeszcze kategoriami komercyjnymi, lecz kategoriami efektu artystycznego i ostatecznego oddania się swojej sztuce, swojemu dziełu - jak Proust właśnie ${ }^{63}$. Nazywa to koniecznością ${ }^{64}$, jakimś wewnętrznym musem, wychodzi na to samo. Czyż Proust, który w noc śmierci jeszcze coś notował na karteczce w związku ze swoim dziełem, nie jest takim wzorem? Maria Janion (trzeba tu przywołać jej inny ważny tekst) wskazuje na umiejętność „transponowania wrażeń" - i to właśnie nazywa ,proustyzmem” Czapskiego ${ }^{65}$. Jego sztuka ma wciąż etykę u swego podłoża, przede wszystkim etykę, a nawet więcej: ideę ofiary życia w imię sztuki. Bo właśnie tę ofiarniczość zauważał w Prouście, który poświęcił salony dla dzieła i zdrowie dla sztuki. Dopiero w tym kontekście staje się jasny wybór obiektu ,francuskich konwersacji” Czapskiego w Griazowcu: W poszukiwaniu straconego czasu Prousta.

\section{Pokłosie Prousta}

Oprócz Czapskiego warto jednak wskazać kilka przykładów literackiego wykorzystania motywów Prousta, a także jego charakterystycznego stylu. Bowiem dzieło Prousta, zanim zostało przyswojone polszczyźnie, znalazło podatny grunt, aby zaszczepić się w polskich kręgach artystycznych, psychologizm rozchodził się szeroką falą, biorąc początek w Wiedniu, na uniwersyteckich katedrach. Duże znaczenie miała też legenda samego autora, jego pustelniczy styl życia i wyniszczający styl pracy, a także, jak widać, szybka i żywa komunikacja z kulturą francuską. O Prouście dyskutują bohaterowie Pożegnania jesieni (1927) Stanisława Ignacego Witkiewicza (Witkacego), na modelu

${ }^{59}$ Zob.: J. Czapski, Proust w Griazowcu, s. 147, 153, 156 (w ostatnim fragmencie chodzi o krótki, pesymistyczny opis postaci barona de Charlus).

${ }^{60}$ Por. zastrzeżenie: „Nie ma w nich śladu jakichkolwiek sensacji osobistych czy ogólnych”; J. Czapski, Wyrwane strony, s. 89. Trochę więcej, ale też bardzo ostrożnie, powiedział na ten temat w rozmowie Świat w moich oczach (s. 86 i n.).

${ }^{61}$ J. Czapski, Wyrwane strony, s. 203.

${ }^{62}$ M. Janion, Dziwaczny wzrost, [w:] Czapski i krytycy, s. 334.

63 „Proust wpada we wściekłość, kiedy brat jego nalega, by się zabrał do leczenia, bo kończył A la recherche — on tym żył i dla tego żył"; J. Czapski, Wyrwane strony, s. 173.

${ }^{64}$ Janusz Marciniak nazwał to nawet „metafizyką konieczności”, por. tegoż, Józef Czapski - metafizyka konieczności, [w:] Czapski i krytycy, s. 397-403.

${ }^{65}$ M. Janion, Artysta przemienienia, [w:] Czapski i krytycy, s. 499. 
wspominania oparta jest konstrukcja słabej wprawdzie, ale głośno komentowanej swego czasu powieści Heleny Boguszewskiej Całe życie Sabiny (1934), odnosi się do niego Tadeusz Peiper w książce Ma lat 22 (1936). Jednak dwa przykłady tekstów, związanych z Poszukiwaniem straconego czasu, trzeba omówić nieco szerzej: chodzi o długie opowiadanie Jarosława Iwaszkiewicza Panny z Wilka $(1932)^{66}$ i debiutancką powieść Tadeusza Brezy Adam Grywatd (1936).

Iwaszkiewicz wysyła swojego bohatera, Wiktora Rubena, na trzytygodniowy urlop do dworu w Wilku, gdzie przed piętnastu laty pracował jako korepetytor wśród sześciu dziewcząt; opowiadanie wypełnia konfrontacja obrazów z czasu młodości z obecnym stanem rzeczy. Iwaszkiewicz inaczej niż Proust rozstrzyga kwestię czasu: Ruben sądzi, że „miniony czas” nie daje się w żaden sposób odzyskać, konfrontacja przeszłości z teraźniejszością pogrąża go raczej w melancholii nieuchronnego przemijania, z której ratuje go - i w tym jest duch biologiczny Iwaszkiewicza - powrót do naturalnego rytmu istnienia, czyli do pracy. Ostatnia scena ukazuje Wiktora, jak w drodze z Wilka, gdzie się pożegnał z paniami (i swoją młodością), co napełniło go głębokim smutkiem, stopniowo pozbywa się tego przygnębienia i zbliżając się do stacji kolejowej, „machał już wesoło swoją teczką"67. Nawiązanie problemowe jest tu wyraźne, konstrukcja zbliżona, powołanie się na Prousta — wprost niemal nazwane:

Słyszał teraz z rozmów swoich inteligentnych przyjaciół, Jurek mu o tym coś mówił, że się ludzie wiele zajmują ideą czasu, że piszą książki o przezwyciężaniu czasu ${ }^{68}$.

Pikanterii temu opowiadaniu dodają informacje biograficzne, dotyczące samego Iwaszkiewicza: otóż w roku 1911 był korepetytorem w majątku Byszewy (okolice Piotrkowa), gdzie jego uczniami było pięciu braci Świerczyńskich, szósty, Józio, był gimnazjalnym kolegą Iwaszkiewicza. Topografia dworku z opowiadania odpowiada, według świadectw współczesnych, topografii dworku w Byszewach. Podobnie jak narrator Poszukiwania z Agostinellim/Albertyną, Iwaszkiewicz postępuje w swoim tekście z Józiem/Julcią. Miłosna noc z Julcią, opisana w Pannach z Wilka, zapamiętana na całe życie przez Rubena (i powtórzona kilka razy), była w istocie miłosną nocą Iwaszkiewicza z owym Józiem, w dziennikach i wywiadach pisarz mówi o tym otwarcie $^{69}$. Panny z Wilka są więc przykładem tekstu, w którym objawia się „,niewypowiadalne pożądanie" (określenie Germana Ritza ${ }^{70}$ ), oczywiście pożądanie homoseksualne. Transpozycja i obyczajowy kamuflaż były tu jeszcze konieczne, lecz dziś pełna lektura tego tekstu musi, zdaniem krytyki ${ }^{71}$, obejmować także ten homoseksualny aspekt tekstu.

Tadeusz Breza w swojej znakomicie napisanej powieści, Adam Grywałd, przywołuje aluzyjnie dzieło Prousta, gdy pisze:

Istnieją przyjaźnie z pewnym posmakiem niewątpliwie erotycznym, ale przecież nie

${ }^{66}$ J. Iwaszkiewicz, Dzieła. Opowiadania, t. 1: Panny z Wilka, Warszawa 1979.

${ }^{67}$ Por. tamże, s. 214.

${ }^{68}$ Tamże, s. 163

${ }^{69}$ J. Iwaszkiewicz: „Ach, Józio, to przecież jeden ze ślicznych braci Świerczyńskich z sąsiedztwa - «panien z Wilka». Julcia to Józio, z którym bez słowa przeżyłem najpiękniejszą przygodę miłosną mojego życia. Scena w łóżku śpiącej Julci to zalążek całego opowiadania. Boże, ten Józio, cóż to był za piękny chłopak!”; Carpenterius (pseud.), Panna z Wilka, Magazyn Kochających Inaczej 1992 nr 22, cyt. za: J. Domagalski, Proust w literaturze polskiej, s. 121.

${ }^{70} \mathrm{G}$. Ritz, Nić w labiryncie pożądania. Gender i płeć w literaturze polskiej od romantyzmu do postmodernizmu, Warszawa 2002, s. $54 \mathrm{i} \mathrm{n.}$

${ }^{71}$ Por.: W. Śmieja, Literatura, której nie ma. Szkice o polskiej „literaturze homoseksualnej”, Kraków 2011. 
zmysłowe. Popularyzując zboczenia i pisząc o nich, częstokroć wyławia się ten posmak. Ludzie, połączeni takimi związkami, niepokoją się, chwyta ich obawa, że popadli w nienormalność, i nie podniety wtrącają ich w niedozwoloności, lecz jedynie świadomość, że to płeć w tym tkwi, że ona ich zniewala. Gdybyśmy nie znali terminów i określeń, nie przyszłoby nam to na myśl. Książki, o których pan mówi, poddają nazwy i pouczenia. Wiemy, jak mamy traktować pewne uczucia w nas samych dostrzeżone. I ten chrzest dopiero nadaje im cechę nieuniknionej rzeczywistości ${ }^{72}$.

Jego powieść powstaje w momencie, gdy psychologizm przeszedł już przez kilka faz, od pierwotnej psychoanalizy Freudowskiej, przez koncepcje Junga i Adlera aż do Watsona i behawioryzmu ${ }^{73}$. Wydaje się, że Breza właśnie w behawioryzmie dostrzegł zrazu właściwą metodę opowiadania o człowieku i jego świecie: skrupulatna obserwacja, precyzyjna analiza zaobserwowanych zjawisk, wielka liczba czasowników oznaczających proces myślenia, zdania dobitne, raczej krótkie i jasno skonstruowane wykształciły typ powieści, który kiedyś nazwałem powieścią analityczną ${ }^{74}$, zorientowaną intelektualnie. W kolejnym, napisanym przed wojną, ale wydanym dopiero pośmiertnie utworze Zawiść, Breza kompromituje tę metodę, pokazując, że brak rzeczywistej komunikacji między ludźmi, uwzględnianie tylko zewnętrznych gestów i zachowań bez wnikania w ich motywy prowadzi do straszliwych pomyłek. Zatem można powiedzieć, że wątek psychologiczny, który tak wiele znaczył w dziele Prousta, znaczy i tutaj, chociaż ujawnia się w swoich późniejszych, zmutowanych postaciach. Natomiast homoseksualizm ujawniany jest tu wprawdzie bardzo delikatnie, ale czytelnie, już bez kulturowego kamuflażu. Końcowy fragment tekstu wskazuje na ślady kontaktu zmysłowego między Grywałdem i jego przyjacielem Mosskiem (jadowita plotka warszawska głosiła, że Grywałd ma gusta Mossek-sualne), lecz cała ta problematyka ujawnia się przede wszystkim w refleksji na ten temat, $\mathrm{w}$ analitycznym zgłębianiu zagadnienia miłości, przyjaźni, inwersji seksualnej. Breza, wraz z pisarzami już wspomnianymi, ale także Zofią Nałkowską (Charaktery, 1922; Granica, 1936), Adolfem Rudnickim (Niekochana, 1936), Marią Kuncewiczową (Twarz mężczyzny, Przymierze z dzieckiem, Cudzoziemka, 1936), Michałem Choromańskim (Zazdrość i medycyna, 1932), tworzą, dość wyraźną grupę pisarzy psychologizujących. Kiedy w 1946 roku, właśnie z Nałkowską, Iwaszkiewiczem i Rudnickim znalazł się w Paryżu, napisał, co następuje:

A poza tym zważmy, że delegacja akurat została złożona z ludzi pióra do pewnego stopnia zawisłych od piśmiennictwa francuskiego. Była to więc $\mathrm{z}$ naszej strony wizyta niezmiernie osobista, wizyta stęsknionych ${ }^{75}$.

Patronem psychologii naukowej jest Freud, ale jej literackim wyrazicielem — Marcel Proust, stąd te wyznania. Do dzisiaj tworzą akademicki standard nauczania w tym zakresie. Polska literatura psychologiczna $z$ lat trzydziestych dwudziestego wieku więcej wyniosła z lektury Prousta niż Freuda, to pewne. Mówi się nawet, że thumaczenie $W$ poszukiwaniu straconego czasu było spóźnione, wiele z jego idei przeniknęło już bowiem wcześniej do powieści polskiej, zdyskontowało nowość Prousta i poniekąd przyswoiło go kulturze polskiej ${ }^{76}$. Czapski wpisuje się $\mathrm{w}$ tę konstelację $\mathrm{z}$ jednej strony jako miłośnik Prousta $\mathrm{i}$ jego namiętny komentator, $\mathrm{z}$ drugiej zaś jako pisarz przeniknięty i urzeczony mentalnym stylem autora swoich licznych ,złotych gwoździ”.

${ }^{72}$ T. Breza, Adam Grywatd, Warszawa 1958, s. 240.

${ }^{73}$ Por.: J. B. Watson, Behaviorism, New York 1925.

${ }^{74}$ M. Dąbrowski, Polska awangarda prozatorska, Warszawa 1995, rozdz. Tadeusz Breza: powieść analityczna, s. 73-97. Zob. także: tegoż, Tadeusz Breza, Warszawa 1982.

${ }^{75}$ T. Breza, Notatnik literacki, Warszawa 1956, s. 230.

${ }^{76}$ Pisałem o tych procesach w książce Polska awangarda prozatorska. 


\section{LITERATURA}

J. Błoński, Widzieć jasno w zachwyceniu. Szkic literacki o twórczości Prousta, Kraków 1985;

T. Breza, Adam Grywatd, Warszawa 1958;

—, Dwugtos o B. Micińskim, Ateneum $1938 \mathrm{nr}$ 2;

-, Notatnik literacki, Warszawa 1956;

Carpenterius (pseud.), Panna z Wilka, Magazyn Kochających Inaczej 1992 nr 22;

J. Czapski, Czytając, Kraków 1990;

—, Marceli Proust, Przegląd Współczesny 1928 nr 71;

—, Patrząc, wstęp, przedmowa i posłowie J. Pollakówna, wyd. II, Kraków 2004;

-, Świat w moich oczach. Rozmowy przeprowadzit Piotr Kłoczowski, Paryż-Ząbki 2001;

-, Wyrwane strony, Warszawa 2010;

Czapski i krytycy. Antologia tekstów, wybór i oprac. M. Kitowska-Łysiak, M. Ujma, Lublin 1996;

M. Dąbrowski, Polska awangarda prozatorska, Warszawa 1995;

—, Tadeusz Breza, Warszawa 1982;

J. Dobraczyński, Proust na ruinach miast Pentapolu, Prosto z Mostu 1939 nr 23;

J. Domagalski, Proust w literaturze polskiej do 1945 roku, Warszawa 1995;

H. Elzenberg, Literatura francuska, Rocznik Literacki 1936;

A. Feuillerat, Comment Marcel Proust a composé son roman, New Haven 1934;

K. I. Gałczyński, Antyfona, Prosto z Mostu 1937 nr 9;

K. Irzykowski, Autobiografizm, Rocznik Literacki 1936;

J. Iwaszkiewicz, Dzieła. Opowiadania, t. 1: Panny z Wilka, Warszawa 1979;

[A. Iwaszkiewiczowa] Adam Podkowiński (pseud.), [b.t.], Pamiętnik Warszawski $1931 \mathrm{nr} 6$;

A. Iwaszkiewiczowa, Conrad a Proust, Twórczość 1984 nr 12;

A. Iwaszkiewiczowa, Szkice $i$ wspomnienia, do druku podała M. Iwaszkiewicz-Wojdowska, Warszawa 1987;

[A. Iwaszkiewiczowa] Adam Podkowiński (pseud.), Sztuka Prousta, Wiadomości Literackie $1932 \mathrm{nr} 40$

W. Karpiński, Portret Czapskiego, Warszawa 2007;

I. Krzywicka, Epos czasu, Wiadomości Literackie 1928 nr 20;

J. Lechoń, Srebrne i czarne, Warszawa1924;

Z. Mianowska, Rocznik Literacki 1939 (dział „Przekłady”);

S. Nalbantian, Aesthetic Autobiography: From Live to Art in Marcel Proust, James Joyce, Virginia Woolf, and Anais Nin, New York 1994;

A. Nowaczyński, Do Prusa, nie do Prousta, Myśl Narodowa 1929 nr 6;

L. Piwiński, Marcel Proust. „W poszukiwaniu straconego czasu”. „W strone Swanna”. „W cieniu zakwitajacych dziewcząt", Życie Literackie 1937 z. 4;

M. Rakowska, Marcel Proust, Tydzień Polski 1922 nr 11;

À la recherche de "La Recherche". Les notes de Joseph Czapski sur Proust au camp de Griazowietz, 1940-1941 / Józef Czapskis Notate zu Proust im Gefangenenlager Grjazovec 1940/41, red. S. Mainberger, N. Stewart, Lausanne 2016;

G. Ritz, Nić w labiryncie pożądania. Gender i pleć w literaturze polskiej od romantyzmu do postmodernizmu, Warszawa 2002;

J. Speina, Marcel Proust w Polsce. „W poszukiwaniu straconego czasu” - międzywojenna recepcja krytycznoliteracka, Pamiętnik Literacki 1992 R. 83 z. 2;

W. Śmieja, Literatura, której nie ma. Szkice o polskiej „literaturze homoseksualnej”, Kraków 2011;

K. Troczyński, Prousta wydanie dla dzieci. Impresje laika, Dziennik Poznański 1937 nr 256;

J. B. Watson, Behaviorism, New York 1925;

T. Żeleński-Boy, Nowe oblicze Prousta, Wiadomości Literackie $1935 \mathrm{nr} 44$;

—, Nowe stońce literatury, Kurier Poranny $1924 \mathrm{nr}$ 45;

—, Pisma, red. H. Markiewicz, t. 13: Obiad literacki. Proust i jego świat, Warszawa 1958. 


\section{JÓZEF CZAPSKI'S PROUST (AGAINST THE BACKDROP OF POLISH RECEPTION)}

The article briefly discusses the reception of Proust's In Search of Lost Time in Poland since the release of its first volume in France until the post-war complete Polish editions. It focuses on the reading of Proust's novel by his Polish translator Tadeusz Żeleński-Boy and literary critic Jan Błoński. Another part of the article is devoted to the references to Proust in works by young Polish writers in the interwar period.

KEY WORDS: Marcel Proust; Józef Czapski; Gryazovets; reception; influence; translation. 